\title{
Pemberdayaan Pertanian dan Kerajinan Batik di Desa Donowarih Kecamatan Karangploso Kabupaten Malang
}

\author{
Waridi Hendro Saputro ${ }^{1 *}$ dan Sudibya ${ }^{2}$ \\ ${ }^{1}$ Prodi Sastra Daerah Fakultas Ilmu Budaya UNS \\ ${ }^{2}$ Prodi Peternakan Fakultas Pertanian UNS \\ *waridihendro@staff.uns.ac.id
}

\begin{abstract}
Abstrak
Desa Donowarih Kecamatan Karangploso Kabupaten Malang terletak di bawah bukit Arjuna. Desa ini merupakan daerah pertanian yang subur dengan tanaman utama palawija, sayur-mayur, buahbuahan dan bunga hias. Pada umumnya pekerjaan di ladang dilakukan oleh para bapak, sedangkan ibu membantu pekerjaan suami. Kehidupan mereka sehar-hari bekerja secara rutinitas sebagai petani, sehingga ketika waktu luang tidak ada sambilan pekerjaan. Mengingat banyaknya waktu luang bagi ibu-ibu maka dipandang perlu adanya peningkatan potensi lingkungan untuk meningkatkan keterampilan dan kemampuannya. Keterampilan yang dimaksud adalah pemberdayaan batik tulis yang sudah ada di masyarakat secara terbatas, yakni di Dusun Supiturang dan ketika itu masih serba terbatas keberadaannya. Prakarsa pertama adalah ibu kepala dusun dan kemudian dikembangkan ke tingkat desa dengan motif yang cukup khas. Model peningkatan batik tulis ini terutama dilakukan oleh ibu-ibu PKK dan selanjutnya diikuti oleh ibu-ibu yang lain. Pelaksanaan kegiatan pada awalnya dilakukan secara bergantian sesuai kesepakatan mereka. Seterusnya dapat dilakukan di rumah masing-masing sesuai dengan waktu yang tersedia. Setelah pembuatan batik tulis selesai, dikumpulkan ke ketua kelompok untuk diproses lebih lanjut. Hasilnya cukup menggembirakan karena ibu-ibu tersebut dapat melakukannya dengan bangga dan senang hati bisa melakukan pembuatan batik tulis.
\end{abstract}

Kata kunci: Pemberdayaan masyarakat, pertanian, batik tulis, dan Desa Donowarih.

\section{Pendahuluan}

\section{a. Latar Belakang Permasalahan}

Istilah KKN atau yang disebut juga dengan Kuliah Kerja Nyata, sudah tidak asing lagi bagi mahasiswa. Kepopulerannya bukan saja semata-mata hanya sekedar mengerjakan atau mempraktikkan teori yang pernah didapat di bangku kuliah dan diaplikasikan sebagai kegiatan yang mewajibkan mahasiswa pada semester akhir, melainkan lebih jauh adanya kewajiban untuk melakukan pengabdian kepada masyarakat. Dengan demikian, para mahasiswa benar-benar melakukan belajar kuliah di Universitas Kehidupan. Sebagai calon pemimpin masa depan, memang sudah sepantasnyalah untuk melakukan kegiatan semacam ini, sehingga ketika esok menjadi pemimpin sudah tidak asing lagi dengan kegiatan-kegiatan dan kehidupan semacam ini. Kehidupan mahasiswa layaknya mozaik gambar, mozaik narasi, mozaik kegiatan, dan mozaik karakter yang kemudian menjadi satu dalam kegiatan bersama masyarakat desa, menjelma menjadi sebuah lukisan yang indah, menjelma menjadi prosa lirik yang menyentuh hati, menjelma menjadi karya yang menggelora, menjelma menjadi pengabdian tiada berujung di tanah air Indonesia.

Desa Donowarih Kecamatan Karangploso Kabupaten Malang Jawa Timur merupakan bagian terindah dari barisan Archipelago Indonesia, tempat mahasiswa UNS berbakti dan mengabdi pada negeri dalam wujud KKN. Semua kiprah mahasiswa terukir sebagai goresan emas dalam pengabdian masyarakat. Kegiatan ini merupakan representasi gelora dan soul para mahasiswa yang 
menyatukan tradisi dengan masa depan, menyatukan kearifan lokal dengan citarasa milenial, menyatukan semua cerita tentang Indonesia yang kaya akan segalanya.

Desa Donowarih Kecamatan Karangploso Kabupaten Malang Provinsi Jawa Timur merupakan wilayah pertanian yang subur dan terletak di bukit Arjuna. Posisinya terletak di sebelah selatan kaki Gunung Arjuna. Jarak Desa Donowarih ke Kecamatan Karangploso sekitar 2,5 kilometer. Desa Donowarih berada pada ketinggian 760 meter di atas permukaan laut. Luas wilayah Desa Donowarih mencapai 1.298.018 ha yang meliputi 4 dusun yaitu Dusun Karangjuwet, Dusun Jara'an, Dusun Karangan dan Dusun Borogragal. Desa Donowarih berbatasan dengan Desa Bocek di sebelah utara, Desa Girimoyo di sebelah timur, Desa Pendem di sebelah selatan, dan Desa Tawangargo di sebelah barat. Jumlah penduduk di Desa Donowarih mencapai 90.085 jiwa dengan 2.492 kepala keluarga. Penduduk berjenis kelamin perempuan sejumlah 4.495 jiwa dan penduduk berjenis kelamin laki-laki sejumlah 4.590 jiwa. Pembagian luas wilayah di Desa Donowarih meliputi tanah sawah seluas 166 ha, tanah ladang seluas 289 ha, hutan seluas 736 ha, pemukiman seluas 147 ha, sedangkan sisanya seluas 39.982 ha digunakan untuk fasilitas umum dan lain-lain. Secara umum wilayah Desa Donowarih mempunyai ciri geologis berupa lahan tanah hitam yang cocok digunakan sebagai lahan pertanian dan perkebunan. Tanaman sayuran, palawija, buah-buahan dan jenis tanaman lainnya banyak ditemukan di daerah ini. Tanaman sayuran meliputi sawi, buncis, kembang kol, terong, kobis, rebung, dan brokoli. Tanaman palawija meliputi kacang tanah, kacang panjang, kedelai, jagung, dan ibu-ubian. Tanaman buah meliputi buah mangga, pepaya, melon dan pisang. Untuk tanaman perkebunan, jenis tanaman tebu dan kopi merupakan tanaman andalan. Kondisi alam yang seperti ini menjadikan sektor pertanian menjadi mata pencaharian utama bagi masyarakat di Desa Donowarih.

\section{b. Tujuan dan Manfaat}

Kegiatan ini bertujuan untuk memberdayakan dan meningkatkan kehidupan warga masyarakat di Desa Donowarih Kecamatan Karangploso Kabupaten Malang dalam mengembangkan dan meningkatkan hasil pertanian dan kerajinan membatik. Batik tulis yang tadinya hanya berkembang di satu dusun, yaitu Dusun Manggisari sudah mulai dikenal di Dusun Supiturang. Tindak lanjut dari kegiatan ini diharapkan batik tulis yang sekarang sudah dikenal juga di Dusun Supiturang dapat berkembang dan dapat menjadi kegiatan sampingan yang dapat menambah penghasilan khususnya bagi Ibu-ibu PKK Desa Donowarih Kecamatan Karangploso. Kabupaten Malang.

Manfaat dari kegiatan ini untuk meningkatkan pendapatan warga masyarakat Desa Donowarih Kecamatan Karangploso Kabupaten Malang. Mereka harus mampu bekerja mandiri dan tidak selalu menggantungkan diri kepada para tengkulak yang selama ini justru mengambil keuntungan yang lebih besar. Mereka harus mampu bersatu-padu mendukung keberadaan Bumdes yang selama ini kurang berfungsi sebagaimana adanya. Bumdes di wilayah ini harus diupayakan dan mampu membantu kehidupan para petani desa dalam menjalankan kehidupannya. Begitu juga tentang keberadaan pengembangan membatik, diharapkan dapat meningkatkan keterampilannya sehingga para ibu-ibu dapat melakukannya di rumah ketika waktu longgar sebagai pekerjaan sampingan dan akhirnya mendapatkan tambahan penghasilan.

\section{c. Landasan Teori}

Kegiatan ini menggunakan analisis kualitatif. Analisis data kualitatif terdiri dari tiga alur kegiatan yang dilakukan secara bersamaan yaitu: reduksi data, sajian data, dan penarikan kesimpulan/verifikasi. Reduksi data merupakan proses pemilihan, pemfokusan, penyederhanaan, abstraksi dan transformasi terhadap data 'kasar' yang diperoleh dari catatan lapangan. Reduksi data merupakan suatu bentuk analisis data yang bertujuan untuk menajamkan, mengelompokkan, memfokuskan, pembuangan yang tidak perlu, dan mengorganisasikan data untuk memperoleh kesimpulan final.

Penyajian data dilakukan dengan menyajikan sekumpulan informasi yang tersusun dalam suatu kesatuan bentuk yang disederhanakan, selektif dalam konfigurasi yang mudah dipakai sehingga 
memberi kemungkinan adanya pengambilan keputusan. Setelah data tersaji secara baik dan terorganisasi maka dilakukan penarikan kesimpulan atau verifikasi (Moleong, 2017: 20-29).

\section{Metode Pelaksanaan}

Metode pengabdian kepada masyarakat meliputi: observasi dan wawancara dengan berbagai pihak terutama sekali yang memangku kepentingan. Dalam observasi, pengumpulan data yang dilakukan dengan cara mengamati dan mencatat secara langsung tentang berbagai hal yang dibutuhkan. Dalam wawancara pengumpulan data yang dilakukan dengan cara melaksanakan tanya jawab langsung kepada warga, perangkat desa, dan organisasi-organisasi desa yang dianggap mengetahui tentang informasi yang dibutuhkan. Kemudian diteruskan dengan model pengembangan berdasarkan kepentingan masyarakat. Untuk mendapatkan data yang akurat sehingga dapat menentukan langkah-langkah berikutnya. Dengan demikian akan dapat diperoleh suatu hasil yang sesuai dengan tujuan yang hendak dicapai dalam kegiatan pengabdian masyarakat ini

\section{Hasil dan Pembahasan \\ a. Kondisi Masyarakat Desa Donowarih}

Desa Donowarih Kecamatan Karangploso Kabupaten Malang memiliki lima fasilitas setingkat Taman Kanak-Kanak (TK) atau Pendidikan Anak Usia Dini (PAUD), tiga fasilitas setingkat Sekolah Dasar (SD), dan tiga fasilitas setingkat Sekolah Menengah Pertama (SMP). Tingkat pendidikan masyarakat pada umumnya berhenti hingga SMP, Pada umumnya masyarakat di sini tidak banyak yang melanjutkan sekolah hingga bangku perkuliahan. Hal ini dikarenakan masih rendahnya keinginan masyarakat untuk meneruskan pendidikan hingga bangku perkuliahan. Selain itu peran masyarakat atau orang tua siswa yang sibuk dalam mengurus ladang dan bekerja serta masih minimnya ilmu pengetahuan. Oleh karena itu jarang untuk membimbing anak-anaknya dalam belajar di rumah dan mengerjakan pekerjaan rumah yang diberikan oleh guru di sekolah. Dengan demikian anak-anak masih kurang keinginannya untuk belajar karena tidak adanya bimbingan serta kontrol dari orang tua.

Secara umum masyarakat Desa Donowarih Kecamaan Karangploso Kabupaten Malang tergolong dalam kelas ekonomi menengah ke bawah. Mayoritas warga Desa Donowarih bekerja pada sektor pertanian. Selain itu ada juga warga yang bekerja di sektor industri dan sektor jasa atau perdagangan, seperti di bidang pemerintahan, perdagangan, angkutan dan jasa keterampilan lainnya. Namun banyak juga warga di Desa Donowarih ini yang masih menganggur. Desa Donowarih memiliki hasil pertanian yang melimpah termasuk juga hasil pertanian yang ada di Dukuh Sumberwangi. Selain dikonsumsi oleh warga sendiri, sebagian besar dijual kepada pengepul dengan harga rendah. Hal ini disebabkan karena kurangnya jaringan pemasaran hasil pertanian. Memang ada beberapa warga di Dukuh Sumberwangi yang langsung menjual hasil pertaniannya ke pasar yang terletak di Kecamatan Karangploso. Namun karena akses jalan yang sulit dan tidak semua warga memiliki kendaraan, membuat sebagian warga di Dukuh Sumberwangi menjual hasil pertanian mereka kepada tengkulak dengan harga yang lebih rendah, apalagi ketika musim panen tiba.

Salah satu dukuh atau dusun yang paling jauh dengan perkotaan adalah Dukuh Sumberwangi. Dukuh ini posisinya terletak di lereng Gunng Arjuna, jaraknya sekitar 23 kilometer dari kota Malang. Faktor geografis yang letaknya jauh dari perkotaan dan letak pemukiman yang saling berdekatan membuat masyarakat Dukuh Sumberwangi masih sangat kental dengan tradisi gotong royong. Setiap ada acara kegiatan apa saja yang diselenggarakan di Dukuh Sumberwangi ini, mereka berbondong-bondong untuk dapat membantu terselenggaranya kegiatan tersebut. Salah satu contoh misalnya, ketika ada salah satu warga masyaraket yang punya kerja geser rumah, mereka dengan cara sukarela untuk membantunya dengan tidak memikirkan biaya atau ongkos. Mulai dari memotong kayu bahan rumah, menyambung kayu dan menyetelnya, mengangkat bahan-bahan bangunan, membuat berbagai makanan dan lain-lain, sampai dengan proses pemindahan rumah selesai. Kegiatan geser rumah ini disebabkan karena tanah di area lokasi rumah tersebut kadangkadang posisinya menjadi miring ketika hujan turun, akhirnya rumah perlu digeser ke posisi tanah yang lebih datar agar tidak terjadi kemiringan lagi. Bentuk kegotongroyongan ini tidak hanya terlihat 
dalam hal gotong royong geser rumah, akan tetapi juga terlihat dalam aktivitas-aktivitas yang lain, misalnya ketika perbaikan jalan-jalan, baik jalan dukuh atau dusun maupun jalan desa, selalu tampak akan nilai kegotongroyongan ini (Margono Slamet, 2003: 46). Bentuk gotong royong inilah yang menjadi ciri khas warga Sumberwangi dalam kehidupan sehari-hari. Nilai gotong royong inilah yang merupakan salah satu model yang dapat merekatkan warga untuk berkumpul dan berbagi cerita bersama. Suasana nilai gotong royong yang penuh rasa kekeluargaan inilah yang dapat diambil intisari khususnya bagi para mahasiswa sebagai bahan atau bekal kehidupan di masa mendatang, terutama ketika menghadapi masyarakat di pedesaan.

\section{b. Sumber Kehidupan Masyarakat Desa Donowarih}

Dukuh Sumberwangi yang posisinya terletak di kawasan Gunung Arjuna ini dianugerahi oleh kekayaan alam yang sangat luar biasa, yakni tanahnya sangat subur untuk tanaman-tanaman yang menjadi kebutuhan masyarakat setempat. Tanahnya berwarna gelap dan berlempung, banyak mengandung zat hara namun juga organisme tanah yang memadai. Dengan demikian menghasilkan lingkungan yang optimal bagi beragam flora dan fauna untuk hidup nyaman. Mulai dari tanaman pangan hingga tanaman hias, hewan ternak hingga hewan peliharaan. Oleh karena itu sangatlah pantas warga masyarakatpun menggantungkan hidupnya pada kekayaan alam yang demikian. Hasil alamnya sungguh melimpah dan menggembirakan sehingga dapat menjadi sumber kehidupan bagi warga masyarakat. Pada kehidupan sehari-hari, mereka kebanyakan melakukan pekerjaan berkebun. Pada umumnya mereka menanam tanaman yang bisa dipakai untuk kebutuhannya sendiri. Hasil panenannya tidak hanya dipakai untuk kebutuhannya sendiri karena berlimpah hasilnya, sehingga mereka juga menjualnya dari hasil panennya itu untuk mencukupi kebutuhan yang lain. Hasil panenannya antara lain labu siam, sawi, singkong, terong, tomat, cabai, kopi dan sayur mayur. Setiap panen mereka menjualnya hasil panen tersebut ke tengkulak yang sudah siap untuk membelinya. Di sinilah sebenarnya yang menjadi permasalahan para petani di desa ini, karena setiap kali musim panen selalu dijualnya kepada para tengkulak. Penentuan harga jual ditentukan oleh para tengkulak, sehingga pada waktu musim panen, pasti harga jualnya akan turun atau lebih rendah. Dengan demikian yang banyak mendapatkan keuntungan lebih besar adalah para tengkulak tersebut. Para tengkulak menguasai sistem pasar karena di samping sebagai penentu harga, juga memiliki fasilitas yang lebih unggul, misalnya mereka juga menguasai tentang usaha transportasi ke pasar. Di samping itu, para tengkulak tersebut begitu kompaknya dalam menghadapi sistem jual-beli antara petani dengan para tengkulak dalam hal penentuan harga jualnya. Hal ini terbukti, ketika ada beberapa petani yang mencoba untuk menjualnya sendiri hasil panennya ke pasar, semua pembeli di pasar tersebut tidak ada yang berani membeli lebih dari yang ditentukan oleh para tengkulak, bahkan malah terjadi sebaliknya, harganya di bawah harga para tengkulak. Dengan demikian akhirnya para petani malah lebih rugi lagi karena harus membayar biaya angkut ke pasar.

Ternyata tidak salahlah kalau memilih lokasi KKN di Desa Donowarih yang membanggakan kegagahan lereng Gunung Arjuna dan memiliki pesona serta kesuburan tanah yang menyemarakkan kehidupan masyarakat petani. Di tengah kehidupan masyarakat yang memiliki semangat dan jiwa pekerja keras, masih ada para tengkulak yang tumbuh subur mendominasi hasil pertanian mereka. Para petani lemah dalam menentukan harga akibat kompaknya para tengkulak yang menguasai pasar hasil pertanian. Kelompok Tani sudah terbentuk tetapi masih kurang memiliki peranan. Kelompok Tani ini ternyata masih belum mampu untuk melawan para tengkulak. Mereka masih sangat lemah dalam menjalankan tugasnya karena belum secara optimal mendapatkan dukungan dari semua anggotanya. Badan Usaha Milik Desa (Bumdes) belum terbentuk dengan baik, eksistensinya masih belum bisa diandalkan untuk menghidupi dirinya sebagai badan usaha. Kinerja para anggotanya masih belum bisa tertata dengan baik karena sistem yang ada di dalamnya. Seandainya Bumdes sudah berjalan sebagaimana mestinya tentu akan berbeda hasilnya dan tentu saja akan memberdayakan para petani sebagai anggotanya. Oleh karena itu pemberdayaan Bumdes di desa ini harus segera ditingkatkan eksistensinya untuk mendukung kehidupan para petani yang berada di dalamnya. Setelah Bumdes bisa berjalan dengan baik, langkah berikutnya adalah memikirkan untuk mendirikan Badan Usaha Milik Desa Bersama (Bumdesma). Kehadiran Bumdes dan Bumdesma ini tentu saja harapannya akan dapat menjawab kepentingan kehidupan masyarakat desa menjadi lebih berdaya. 
Dengan demikian akan dapat mengusir para tengkulak tersebut dan warga masyarakat akan dapat menikmati hasil pertanian yang sesungguhnya, yakni tidak lagi dijajah oleh para tengkulak. Badan Usaha Milik Desa Bersama (Bumdesma) bisa diupayakan berdiri di desa ini, dengan tujuan memberdayakan masyarakat dari, oleh, dan untuk masyarakat sendiri. Di sekitar Malang sudah terdapat Bumdesma yang keberadaannya cukup terkenal, misalnya Bumdesma Singosari. Oleh karena itu pemerintah daerah setempat perlu segera belajar dan studi banding ke Bumdesma Singosari tersebut Keberadaan Bumdesma sangat diharapkan di desa ini sehingga dapat memberdayakan masyarakat dan para petani tidak akan bergantung lagi dengan para tengkulak yang menguasai pasar. Dengan adanya Bumdesma Singosari yang sudah ada dan tidak terlalu jauh keberadaannya dengan desa ini, semoga ada uluran tangan dari pemda setempat untuk menindaklanjutinya. Petani adalah rakyat kecil yang keberadaannya sangat lemah. Bumdesma adalah satu-satunya harapan mereka untuk mendampingi dan memberdayakan mereka.

\section{c. Tingkat Pendidikan Desa Donowarih}

Banyaknya warga masyarakat yang hanya menamatkan pendidikan di bangku Sekolah Menengah Pertama (SMP) disebabkan karena masih rendahnya keinginan mereka untuk melanjutkan pendidikan ke jenjang lebih tinggi dan bercita-cita tinggi. Sebagian besar dari mereka sudah terbiasa bekerja di ladang sejak kecil sehingga yang menjadi cita-cita mereka adalah meneruskan ladang milik orang tua masing-masing. Dalam keadaan yang seperti ini tentu saja sangat dibutuhkan adanya tokoh masyarakat yang bisa memberikan pemahaman tentang betapa pentingnya pendidikan di era milenial. Masyarakat Desa Donowarih khususnya di Dukuh Sumberwangi terbiasa menghabiskan hari-hari mereka di ladang dan selain itu jarak rumah yang satu dengan yang lain cukup jauh sehingga masing-masing dari warganya terlihat kurang akrab antara satu dengan yang lain. Faktor vakumnya kebudayaan lokal juga disebabkan oleh kesibukan masyarakat untuk bekerja di ladang, sedangkan pemudanya kurang memiliki ketertarikan untuk melestarikan kebudayaan lokal di daerah ini (Totok Mardikanto, 2007:76).

\section{d. Peningkatan Ekonomi Masyarakat Desa Donowarih}

Ekonomi masyarakat merupakan salah satu hal yang tidak dapat lepas dari perkembangan suatu wilayah. Pertumbuhan perekonomian yang pesat menjadi indikator penting kemajuan sebuah wilayah. baik itu wilayah dalam cakupan yang sempit maupun wilayah dengan cakupan yang lebih luas. Masyarakat Desa Donowarih memiliki potensi yang cukup tinggi untuk dapat meningkatkan perekonomian mereka. Namun, penduduk Desa Donowarih sendiri masih kurang berinisiatif untuk membangun sektor perekonomiannya sehingga tidak adanya pembaharuan dalam meningkatkan sektor ekonomi di desanya.

Masyarakat Desa Donowarih pada umumnya memiliki matapencaharian sebagai petani. Pertanian yang utama adalah padi dan sebagai tanaman yang diandalkan adalah palawija. Tanahnya sangat subur karena dekat pegunungan dengan mata air yang cukup. Dengan demikian tanaman palawija menjadi andalan daerah tersebut. Di samping bidang pertanian juga terdapat usaha-usaha lainnya, misalnya yang bergerak dalam bidang jasa dan juga di bidang industri. Namun sebagian besarnya dikerjakan oleh bapak-bapak, sedangkan ibu-ibu pada umumnya hanya membantu pekerjaan di rumah ataupun pekerjaan yang di ladang. Sebagai pekerjaan samping di rumah, sebagian kecil saja yang bisa melakukannya. Oleh karena itu perlu adanya peningkatan penghasilan untuk mensejahterakan kehidupan mereka, maka dipandang perlu untuk meningkatkan eksistensi Badan Usaha Milik Desa (Bumdes) sesuai dengan fungsinya, sehingga keberadaannya betul-betul dapat membantu kehidupan para petani yang selama ini masih dijajah oleh para tengkulak dalam menentukan harga panennya. Dengan demikian akan dapat mensejahterakan hidupnya sesuai dengan harapannya. Selanjutnya, untuk lebih meningkatkan potensinya, maka dipandang perlu untuk menyelenggarakan workshop batik tulis, agar para ibu-ibu bisa melakukannya sebagai pekerjaan sampingan.

Workshop batik tulis adalah salah satu program utama dalam pemberdayaan masyarakat Desa Donowarih. Program ini diselenggarakan untuk menambah kreativitas dan keterampilan warga masyarakat terutama untuk para ibu-ibu. Sebenarnya sebelum kegiatan workshop ini dilaksanakan 
sudah ada keterampilan membatik untuk dusun lain namun untuk dusun Supiturang belum ada. Dengan demikian dipandang perlu untuk mengembangkan sampai ke dusun yang lain, sehingga program ekonomi masyarakat merupakan salah satu hal yang tidak dapat lepas dari perkembangan suatu wilayah. Pertumbuhan perekonomian yang pesat menjadi indikator penting kemajuan sebuah wilayah. baik itu wilayah dalam cakupan yang sempit maupun wilayah dengan cakupan yang lebih luas. Masyarakat Desa Donowarih memiliki potensi yang cukup tinggi untuk dapat meningkatkan perekonomian mereka. Namun, penduduk Desa Donowarih sendiri masih kurang berinisiatif dalam membangun sektor perekonomiannya sehingga tidak adanya pembaharuan dalam meningkatkan sektor ekonomi di desanya.

\section{Kesimpulan}

Untuk meningkatkan pendapatan masyarakat di Desa Donowarih Kecamatan Plosorejo Kabupaten Malang, perlu adanya pemberdayaan potensi lingkungan dan sumberdaya masyarakat, berupa pemanfaatan Bumdes secara maksimal untuk menghindarkan diri dari para tengkulak yang selalu menguasai sistem pasar yang akhirnya merugikan para petani. Di samping itu juga menyelenggarakan kegiatan workshop batik tulis untuk ibu-ibu. Kegiatan ini diikuti dan diperuntukkan untuk para ibu PKK dari desa tersebut. Dengan adanya workshop ini, para ibu PKK mendapatkan kesempatan untuk meningkatkan keterampilan mereka yang akhirnya juga akan menambah penghasilan mereka untuk menunjang kehidupan rumah tangga. Pembuatan batik tulis ini juga menjadikan daerah tersebut memiliki keunikan tersendiri. Dengan adanya pembuatan batik tulis ini, ke depan juga bertujuan untuk membuat pakaian batik seragam untuk ibu-ibu PKK dan Karang Taruna di desa tersebut. Dengan demikian akan dapat meningkatkan kesejahteraan mereka.

Kegiatan yang berupa penguatan Badan Usaha Milik Desa (Bumdes) memiliki manfaat yang besar bagi warga masyarakat petani karena dengan kuatnya eksistensi Bumdes akan dapat melawan para tengkulak yang selalu mengambil untung yang sebesar-besarnya bagi petani ketika saat panen. Dengan adanya Bumdes yang kuat dan tangguh tentu saja akan mensejahterakan para petani, karena Bumdes berfungsi dari, olen dan untuk masyarakat.

\section{Ucapan Terima Kasih}

Pertama-tama Penulis mengucapkan terima kasih yang sebesar-besarnya kepada Bapak Rektor Universitas Sebelas Maret yang telah memberikan kesempatan untuk melakukan kegiatan ini. Selanjutnya ucapan terima kasih juga disampaikan kepada Bapak Kepala Desa Donowarih Kecamatan Karangploso Kabupaten Malang yang telah mengijinkan para mahasiswa peserta KKN UNS Periode Januari-Februari 2020 di desa tersebut. Kemudian, ucapan terima kasih juga saya sampaikan kepada para mahasiswa peserta KKN yang telah banyak membantu kegiatan ini.

\section{Daftar Pustaka}

Margono Slamet, 2003. Membentuk Pola Perilaku Manusia Pembangunan. IPB Press, Bogor.

Moleong, Lexy J., 2017. Metodologi Penelitian Kualitatif. PT Remaja Rosdakarya, Bandung.

Totok Mardikanto, 2007. Penyuluhan Pembangunan Kehutanan. Pusat Penyuluhan Kehutanan, Jakarta. 